\title{
Crystal structure and solid-state properties of discrete hexa cationic trinuclear zinc triazole cluster
}

\author{
CHATLA NAGA BABU, PALADUGU SURESH, ARRURI SATHYANARAYANA, \\ PRASENJIT DAS and GANESAN PRABUSANKAR* \\ Department of Chemistry, Indian Institute of Technology Hyderabad, ODF Estate, Yeddumailaram, \\ Telangana, India 502205 \\ e-mail: prabu@iith.ac.in
}

MS received 16 March 2015; revised 21 April 2015; accepted 24 April 2015

\begin{abstract}
A linear trinuclear cluster of the type $\left[\left\{\mathrm{Zn}_{3}(\mathrm{HTrz})_{6}\left(\mathrm{H}_{2} \mathrm{O}\right)_{6}\right\}^{6+}\left(\mathrm{NO}_{3}^{-}\right)_{6}\left(\mathrm{H}_{2} \mathrm{O}\right)\right](\mathbf{Z n T})$ has been synthesized by one-pot reaction between 1,2,4-triazole and $\mathrm{Zn}\left(\mathrm{NO}_{3}\right) \cdot 6 \mathrm{H}_{2} \mathrm{O}$. Molecule consists of three $\mathrm{Zn}^{2+}$ ions linearly connected by 1,2,4-triazole with tri-fold symmetry. The coordination geometry around the zinc centre is octahedral with zinc-zinc separation of $3.810 \AA$ A. The coordination environment of central $\mathrm{Zn}^{2+}$ ion is satisfied by nitrogen atoms of six 1,2,4-triazoles, while the geometry of terminal $\mathrm{Zn}^{2+}$ ions is fulfilled by nitrogen atoms of three 1,2,4-triazoles and three water molecules. The thermal and absorption properties of $\mathbf{Z n T}$ have been reported for the first time.
\end{abstract}

Keywords. Zinc; trizole; clusters; cationic compounds.

\section{Introduction}

The evolution of a new strategy for noetic design of polynuclear zinc clusters has led to special attention in supramolecular chemistry. ${ }^{1}$ The choice of multidentate ligands and zinc often leads to a well defined cluster with special properties. ${ }^{2-4}$ For example, the zinc-rich clusters formed by binding of nitrogen donor in organic ligands are attractive building blocks to induce unusual thermal and optical properties to the materials. ${ }^{5,6}$ These molecular assemblies often represent as models for the active sites of enzymes. ${ }^{7}$ Controlling the nuclearity of zinc cluster complexes is one of the most challenging tasks, which may be solved using multidentate $\mathrm{N}$-donor ligands. ${ }^{1-4}$

The multidentate $\mathrm{N}$-donor ligands can be used in the construction of clusters or multi-dimensional coordination polymers. Of the many nitrogen-containing heterocycles, only the 1,2,4-triazole is particularly well established as being able to facilitate the formation of trinuclear complexes bridged by the adjacent nitrogen atoms. ${ }^{8}$ Trinuclear complexes can be used as "cut out" of extended metal network to understand the magnetic and/or electrochemical behavior due to the synergism between metal centers. They can also be treated as bioinorganic models, to understand the mechanism of complex biological systems (e.g., metalloenzymes) or to reproduce their catalytic activity. ${ }^{6,7}$

\footnotetext{
*For correspondence
}

For example, the first structurally characterized trinuclear complex $\left[\mathrm{Ni}_{3}(\mathrm{Htrz})_{6}\left(\mathrm{H}_{2} \mathrm{O}\right)_{6}\right]\left(\mathrm{NO}_{3}\right)_{6} \cdot 2 \mathrm{H}_{2} \mathrm{O}$ was reported by Reimann et al. ${ }^{9}$ Subsequently several triazole bridged trinuclear clusters of $\mathrm{Mn}, \mathrm{Fe}, \mathrm{Co}$ and Ni were synthesized and structurally characterized. ${ }^{8}$ However, similarity of molecular assembly of copper and zinc is very rare. ${ }^{7}$ In particular, the triazole coordinated zinc assembly leads to the formation of insoluble coordination polymers. The only linear trinuclear zinc triazole assembly reported upto now is $\left[\mathrm{Zn}_{3}(\mathrm{EtTrz})_{6}\left(\mathrm{H}_{2} \mathrm{O}\right)_{6}\right]\left[\mathrm{CF}_{3} \mathrm{SO}_{3}\right]_{6}$ $\left[\mathbf{Z n} \mathbf{T}^{\mathbf{E}}\right.$ ], derived from 4-ethyl-1,2,4-triazole, where the zinc-zinc separation is $3.815 \AA .{ }^{10}$ Of late, the $\left[\mathrm{Zn}_{3}(\mathrm{HTrz})_{6}\right.$ $\left.\left(\mathrm{H}_{2} \mathrm{O}\right)_{6}\right]^{6+}$ was isolated with decavanadate complex, $\left[\mathrm{V}_{10} \mathrm{O}_{28}\right]^{6+}$ as a counter ion in $\left[\mathrm{Zn}_{3}(\mathrm{Htrz})_{6}\left(\mathrm{H}_{2} \mathrm{O}\right)_{6}\right]$ $\left[\mathrm{V}_{10} \mathrm{O}_{28}\right] \cdot 10 \mathrm{H}_{2} \mathrm{O} \cdot \mathrm{Htrz}(\mathbf{Z n T V})$ using 1,2,4-triazole, where the zinc-zinc separation is $3.805 \AA .{ }^{11}$ Nevertheless, the strategies to isolate $\left[\mathrm{Zn}_{3}(\mathrm{HTrz})_{6}\left(\mathrm{H}_{2} \mathrm{O}\right)_{6}\right]^{6+}$ from unsubstituted 1,2,4-triazole is not known. Thus, we report the synthesis, structural, optical and thermal properties of $\left[\left\{\mathrm{Zn}_{3}(\mathrm{HTrz})_{6}\left(\mathrm{H}_{2} \mathrm{O}\right)_{6}\right\}^{6+}\left(\mathrm{NO}_{3}^{-}\right)_{6}\left(\mathrm{H}_{2} \mathrm{O}\right)\right](\mathbf{Z n T})$ obtained from the reaction between unsubstituted 1,2,4-triazole and $\mathrm{Zn}\left(\mathrm{NO}_{3}\right) \cdot 6 \mathrm{H}_{2} \mathrm{O}$.

\section{Experimental}

\subsection{General Procedures}

$\mathrm{Zn}\left(\mathrm{NO}_{3}\right)_{2} \cdot 6 \mathrm{H}_{2} \mathrm{O}$ (Merck) and 1,2,4-triazole (Merck) were purchased from commercial sources. FT-IR measurement 
(neat) was carried out on a Bruker Alpha-P Fourier transform spectrometer. The thermogravimetric analysis (TGA) was performed using a TA-SDT Q600, Tzeropress. The UV-vis spectra were measured on a T90+ UVvisible spectrophotometer. Elemental analyses were performed by the Euro EA Elemental Analysis. The crystal structure of $\mathbf{Z n T}$ was measured on an Oxford Xcalibur 2 diffractometer with standard 4-circle kappagoniometer, Eos detector (Active area $92 \mathrm{~mm}$ diagonal) and two X-ray sources one of which is Supernova $\mathrm{Cu}$ source (wave length $1.5418 \AA$ ) with focusing mirrors. A suitable crystal was selected and mounted on a Gemini

Table 1. Crystallographic data, details of data collection and structure refinement parameters for $\mathbf{Z n T}$.

\begin{tabular}{ll}
\hline Empirical formula & $\mathrm{C}_{12} \mathrm{H}_{30} \mathrm{Zn}_{3} \mathrm{~N}_{24} \mathrm{O}_{26}$ \\
\hline Formula weight & 1122.71 \\
Temperature $(\mathrm{K})$ & $150(2)$ \\
Crystal system & Monoclinic \\
Space group & $\mathrm{P} 2(1) / \mathrm{n}$ \\
$a, \AA$ & $13.153(3)$ \\
$b, \AA$ & $11(2)$ \\
$c, \AA$ & $14.333(3)$ \\
$\alpha,{ }^{\circ}$ & 90 \\
$\beta,{ }^{\circ}$ & $114.17(3)$ \\
$\gamma,{ }^{\circ}$ & 90 \\
Volume, $\AA^{3}$ & $2033.0(7)$ \\
$Z$ & 2 \\
$\rho_{\text {calc }}, \mathrm{mg} \mathrm{mm}^{-3}$ & 1.834 \\
$\mu, \mathrm{mm}{ }^{-1}$ & 1.874 \\
$F(000)$ & 1136 \\
Data collected & 7764 \\
Unique data & 3829 \\
$R_{\text {int }}$ & 0.0251 \\
$\mathrm{GOF}$ on $F^{2}$ & 1.077 \\
$R_{1}(I>2 \sigma(I))$ & 0.0424 \\
w $R_{2}(I>2 \sigma(I))$ & 0.1224 \\
\hline
\end{tabular}

Table 2. Selected bond lengths $[\AA]$ and angles $\left[^{\circ}\right]$ of $\mathbf{Z n T}$.

\begin{tabular}{|c|c|c|c|}
\hline \multicolumn{4}{|l|}{ Bond lengths [Å] } \\
\hline $\mathrm{N}(1)-\mathrm{Zn}(1)$ & $2.126(3)$ & $\mathrm{N}(8)-Z n(1)$ & $2.118(3)$ \\
\hline $\mathrm{N}(3)-\operatorname{Zn}(2)$ & $2.189(3)$ & $\mathrm{O}(1)-\mathrm{Zn}(1)$ & $2.095(3)$ \\
\hline $\mathrm{N}(4)-\mathrm{Zn}(2)$ & $2.155(3)$ & $\mathrm{O}(2)-\mathrm{Zn}(1)$ & $2.123(3)$ \\
\hline $\mathrm{N}(5)-\mathrm{Zn}(2)$ & $2.176(3)$ & $\mathrm{O}(3)-\mathrm{Zn}(1)$ & $2.071(3)$ \\
\hline $\mathrm{N}(6)-\mathrm{Zn}(1)$ & $2.143(3)$ & & \\
\hline \multicolumn{4}{|l|}{ Bond angles [deg] } \\
\hline $\mathrm{O}(3)-\mathrm{Zn}(1)-\mathrm{O}(1)$ & $89.54(16)$ & $\mathrm{N}(8)-\mathrm{Zn}(1)-\mathrm{N}(6)$ & $89.32(12)$ \\
\hline $\mathrm{O}(3)-\mathrm{Zn}(1)-\mathrm{O}(2)$ & $90.93(15)$ & $\mathrm{O}(1)-\mathrm{Zn}(1)-\mathrm{N}(6)$ & $90.90(14)$ \\
\hline $\mathrm{O}(1)-\mathrm{Zn}(1)-\mathrm{O}(2)$ & $87.22(14)$ & $\mathrm{N}(8)-\mathrm{Zn}(1)-\mathrm{N}(1)$ & $94.20(11)$ \\
\hline $\mathrm{O}(3)-\mathrm{Zn}(1)-\mathrm{N}(8)$ & $90.17(14)$ & $\mathrm{N}(1)-\mathrm{Zn}(1)-\mathrm{N}(6)$ & $91.57(11)$ \\
\hline $\mathrm{N}(8)-\mathrm{Zn}(1)-\mathrm{O}(2)$ & $91.16(13)$ & $\mathrm{N}(4)-\mathrm{Zn}(2)-\mathrm{N}(5)$ & $89.70(11)$ \\
\hline $\mathrm{O}(3)-\mathrm{Zn}(1)-\mathrm{N}(1)$ & $91.14(14)$ & $\mathrm{N}(4)-\mathrm{Zn}(2)-\mathrm{N}(3)$ & $89.43(11)$ \\
\hline $\mathrm{O}(1)-\mathrm{Zn}(1)-\mathrm{N}(1)$ & $87.44(12)$ & $\mathrm{N}(5)-\mathrm{Zn}(2)-\mathrm{N}(3)$ & $91.25(11)$ \\
\hline $\mathrm{O}(2)-\mathrm{Zn}(1)-\mathrm{N}(6)$ & $86.40(13)$ & & \\
\hline
\end{tabular}

E goniometer. Data were collected at $150 \mathrm{~K}$ using Oxford Cryojet Low-Temperature device. The structure of $\mathbf{Z n T}$ was solved by direct methods using the SIR-97 program $^{12}$ and refined with a full matrix least-squares method on F2 using the SHELXL-97 program. ${ }^{13,14}$ No hydrogen atoms are given for a water molecule of $\mathrm{O}(13)$. Non-hydrogen atoms were anisotropically refined. $\mathrm{H}$ atoms were included in the refinement in calculated positions riding on their carrier atoms. No restraint has been made for any of the compounds. The function minimized was $\left[\sum \mathrm{w}\left(F_{\mathrm{o}}^{2}-F_{\mathrm{c}}^{2}\right)^{2}\right]\left(\mathrm{w}=1 /\left[\sigma^{2}\left(F_{\mathrm{o}}^{2}\right)+(a P) 2+\right.\right.$ $b P])$, where $P=\left(\max \left(F_{\mathrm{o}}^{2}, 0\right)+2 F_{\mathrm{c}}^{2}\right) / 3$ with $\sigma^{2}\left(F_{\mathrm{o}}^{2}\right)$ from counting statistics. The functions $R_{1}$ and $\mathrm{w} R_{2}$ were $\left(\sum|| F_{\mathrm{o}}|-| F_{\mathrm{c}} \mid\right) / \sum\left|F_{\mathrm{o}}\right|$ and $\left[\sum \mathrm{w}\left(F_{\mathrm{o}}^{2}-F_{\mathrm{c}}^{2}\right)^{2} / \sum\left(\mathrm{w} F_{\mathrm{o}}^{4}\right)\right]^{1 / 2}$, respectively. Crystallographic data for the structures are provided in tables $1-2$. Structural diagrams were generated using the Diamond3.0 and Mercury3.1 program.

\subsection{Synthesis of $\left[\left\{\mathrm{Zn}_{3}(\mathrm{HTrz})_{6}\left(\mathrm{H}_{2} \mathrm{O}\right)_{6}\right]^{6+}\left(\mathrm{NO}_{3}^{-}\right)_{6}\left(\mathrm{H}_{2} \mathrm{O}\right)\right]$ (ZnT)}

1,2,4-triazole (1.4 mmol) in $\mathrm{MeOH} / \mathrm{H}_{2} \mathrm{O}(1: 1)$ was carefully layered on a solution of $\mathrm{Zn}\left(\mathrm{NO}_{3}\right) \cdot 6 \mathrm{H}_{2} \mathrm{O}(0.7 \mathrm{mmol})$ in $\mathrm{MeOH} / \mathrm{H}_{2} \mathrm{O}$ (1:1). Subsequently the pale yellow reaction mixture was stored at $8^{\circ} \mathrm{C}$ for few days to obtain the colorless crystals of $\mathbf{Z n T}$ as an insoluble solid. Yield: $62 \%$ (based on $\mathrm{Zn}\left(\mathrm{NO}_{3}\right) \cdot 6 \mathrm{H}_{2} \mathrm{O}$ ). M.p.: $208-210^{\circ} \mathrm{C}$ (decomp.). Anal. Calcd (\%) for $\mathrm{C}_{15} \mathrm{H}_{41} \mathrm{~N}_{24} \mathrm{O}_{25} \mathrm{Zn}_{3}$ (1153.78): $\mathrm{C}, 15.61$; $\mathrm{H}, 3.58$; N, 29.14; found: C, 15.4; H, 3.5; N, 29.2. FT-IR (neat, $\bar{v}, \mathrm{~cm}^{-1}$ ): 3628(w), 3274(w), 3124(m), 1641(m), 1541(s), 1389(s), 1305(vs), 1273(s), 1161(m), 1053(m), $1013(\mathrm{~m}), 630(\mathrm{~s}) \mathrm{cm}^{-1}$. Solid-state UV-vis: $\lambda_{\max } 220$ and $292 \mathrm{~nm}$.

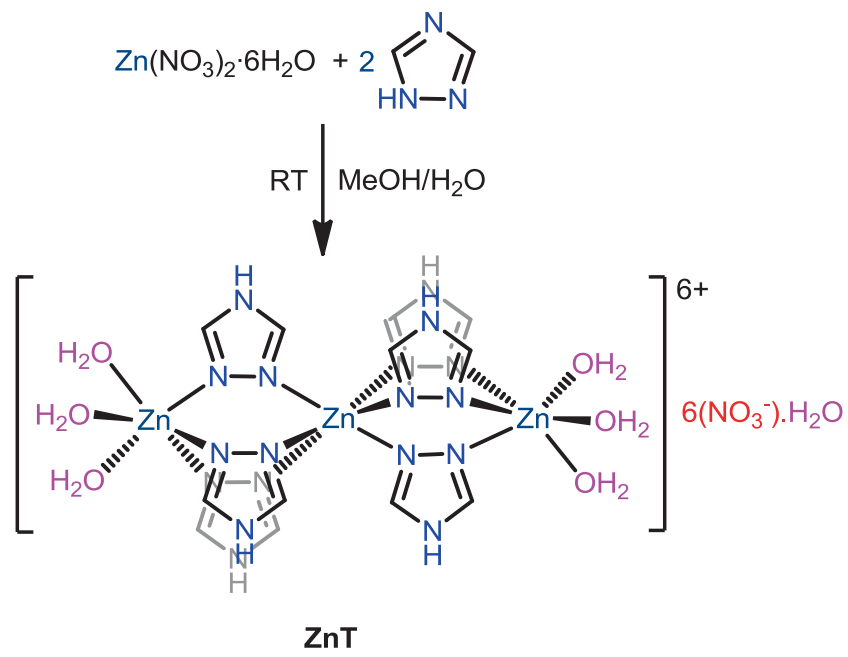

Scheme 1. Synthesis of ZnT. 


\section{Result and Discussion}

\subsection{Synthesis and spectral studies}

The synthesis of trinuclear zinc compound ZnT was accomplished by layering 1,2,4-triazole solution in $\mathrm{MeOH}$ to a solution of $\mathrm{Zn}\left(\mathrm{NO}_{3}\right)_{2} \cdot 6 \mathrm{H}_{2} \mathrm{O}$ in $\mathrm{H}_{2} \mathrm{O}$ at RT (scheme 1). Insoluble colorless crystals were obtained at $8^{\circ} \mathrm{C}$ in good yield $(60 \%)$. The purity of bulk sample was confirmed by $\mathrm{CHN}$ analysis. Furthermore, the solid state structure was confirmed by FT-IR, solidstate UV-vis, TGA and single crystal X-ray diffraction techniques. FT-IR spectrum shows a characteristic peak for the $\mathrm{N}-\mathrm{H}$ stretching frequency at $3124 \mathrm{~cm}^{-1}$. The presence of free $\mathrm{NO}_{3}^{-}$ions $\left(1389 \mathrm{~cm}^{-1}\right)$ and water molecules $\left(3625\right.$ and $3274 \mathrm{~cm}^{-1}$ ) are confirmed by FTIR. Solid-state UV-visible absorption spectra of $\mathbf{Z n T}$ is depicted in figure 1a that shows two absorption bands centered at 220 and $292 \mathrm{~nm}$, which can be assign to the spin-allowed intra-ligand $\pi$ to $\pi *$ transition.

\subsection{Thermogravimetric analyses}

In order to understand the thermal stability of $\mathbf{Z n T}$, thermo gravimetric analysis (TGA) was carried out from $30-1000^{\circ} \mathrm{C}$ at $10^{\circ} \mathrm{C} / \mathrm{min}$ under $\mathrm{N}_{2}$ atmosphere (figure $1 \mathrm{~b}$ ). The decomposition pathway of $\mathbf{Z n T}$ occurs through well defined three steps, from 100 to $242^{\circ} \mathrm{C}$ with $47 \%$ weight
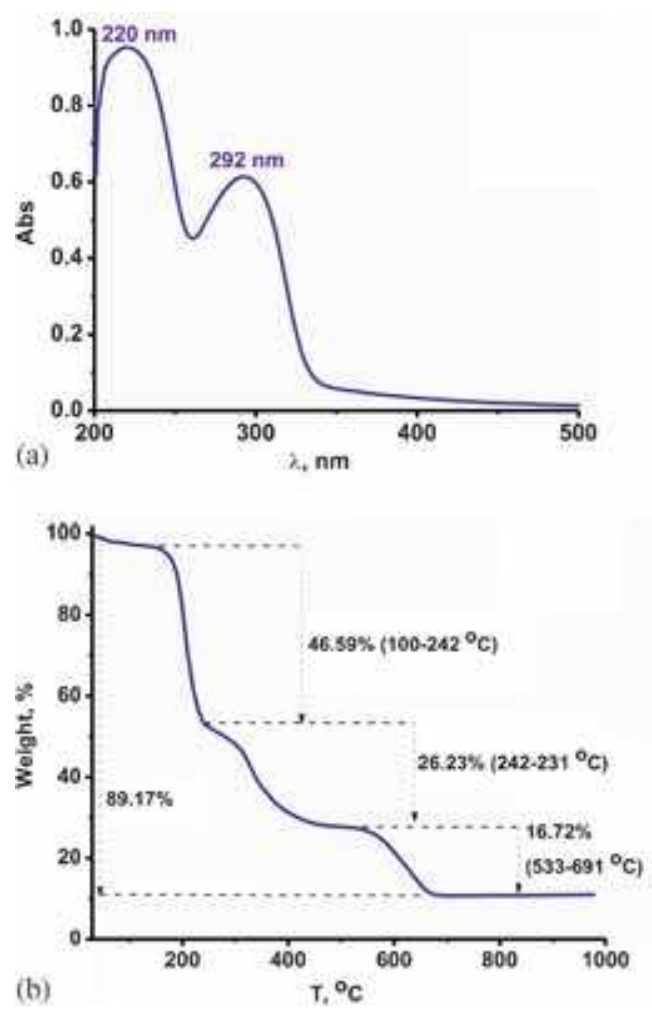

Figure 1. (a) Solid state UV-vis absorption spectrum of ZnT. (b) TGA profile of $\mathbf{Z n T}$. loss, from 242 to $231{ }^{\circ} \mathrm{C}$ with $26 \%$ weight loss and from 533 to $691{ }^{\circ} \mathrm{C}$ with $17 \%$ weight loss. The total weight loss is $90 \%$. A small weight loss near about $2 \%$ till $100^{\circ} \mathrm{C}$ can be attributed to loss of moisture. The weight loss of about $47 \%$ from $100-242^{\circ} \mathrm{C}$ can be ascribed to the loss of six $\mathrm{NO}_{3}^{-}$and seven $\mathrm{H}_{2} \mathrm{O}$ molecules, which is close to the calculated weight percentage (43\%) for six $\mathrm{NO}_{3}^{-}$and seven $\mathrm{H}_{2} \mathrm{O}$. Subsequently, weight loss of $33 \%$ in two stages from 242 to $691{ }^{\circ} \mathrm{C}$ can be assigned to the decomposition of triazole ligands.

\subsection{Description of the crystal structure}

The solid-state structure of $\mathbf{Z n T}$ was unambiguously determined by the single crystal X-ray diffraction technique (figures 2 and 3). Compound $\mathbf{Z n T}$ crystallizes in the monoclinic space group $P 21 / n$ and the asymmetric unit consists of nearly $\left[\mathrm{Zn}_{1.5}(\mathrm{Htrz})_{3}\left(\mathrm{H}_{2} \mathrm{O}\right)_{3}\right] \cdot\left(\mathrm{NO}_{3}\right)_{3} \cdot \mathrm{H}_{2} \mathrm{O}$ (table 1). ${ }^{12,13}$ The selected bond lengths and angles are assembled in table 2. The molecule is a hexa cationic

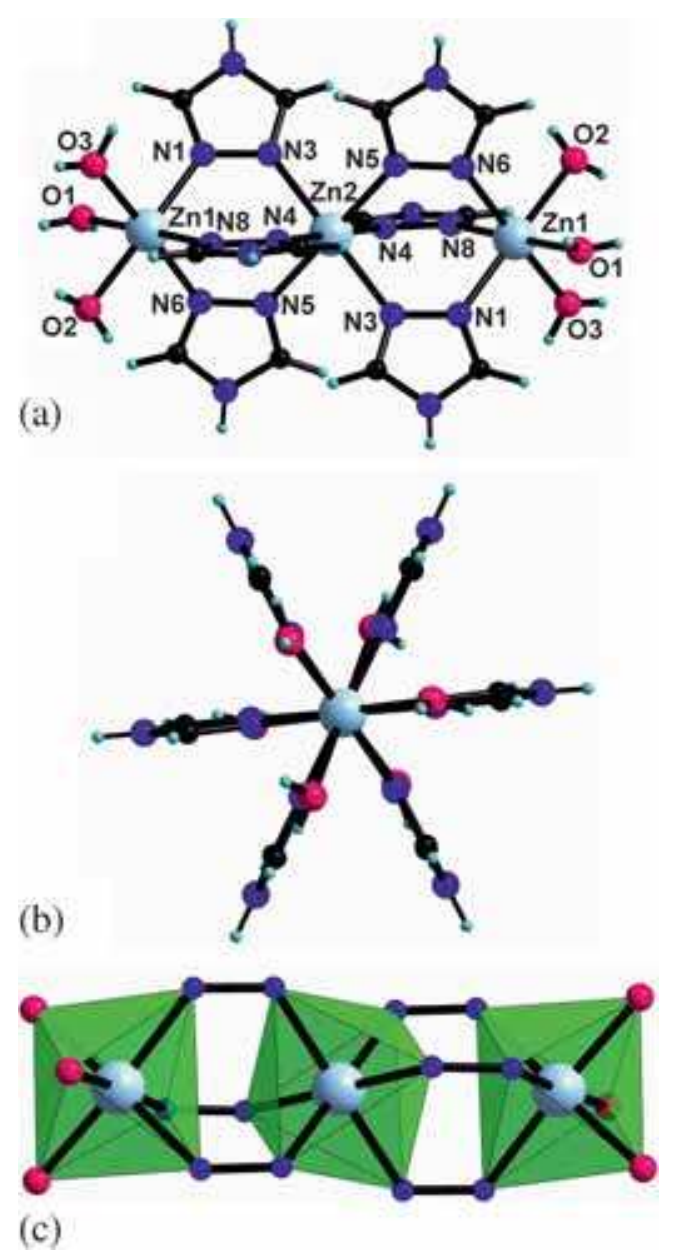

Figure 2. (a) Molecular structure of $\mathbf{Z n T}$. The three $\mathrm{NO}_{3}^{-}$ and one water molecule are omitted for clarity; (b) Molecular structure of $\mathbf{Z n T}$ viewed along $\mathrm{Zn}$ axis. The three $\mathrm{NO}_{3}^{-}$ and one water molecule are omitted for clarity; (c) The core structure of $\mathbf{Z n T}$. 


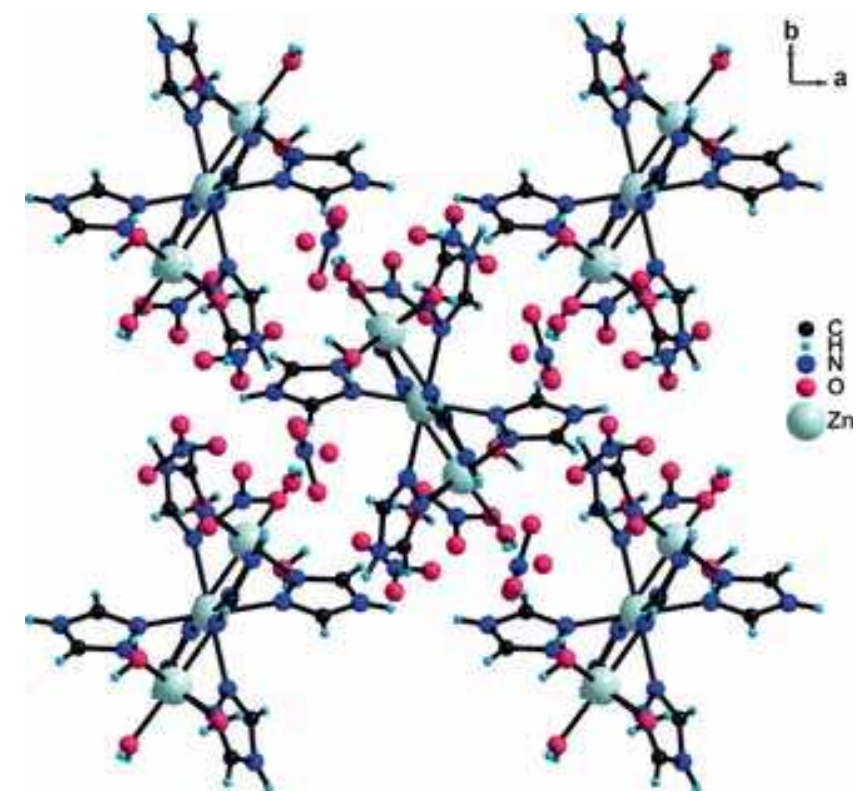

Figure 3. The molecular packing of $\mathbf{Z n T}$ view along $\mathrm{c}$ axis.

zinc trimetallic assembly connected by 1,2,4-triazole ligands with three-fold centro-symmetry along the zinc center (figure 2b). 1,2,4-triazole acts as a $\mu^{2}$ bridging ligand to connect zinc centers in a straight line. Zinc atoms are hexacoordinated with two types of coordination environments, namely, homoleptic ( $\mathrm{Zn}(2))$ and heteroleptic $(\mathrm{Zn}(1))$ coordination environments (figure $2 \mathrm{c}$ ). Coordination environment of central zinc atom, $\mathrm{Zn}(2)$ is fulfilled by six $\mu^{2}$ bridging 1,2,4-triazole ligands, while the $\mathrm{Zn}(1)$ is satisfied by three water molecules and three $\mu^{2}$ bridging 1,2,4-triazole ligands. Central zinc atom $(\mathrm{Zn}(2))$ shows nearly perfect octahedron geometry, while the terminal zinc atoms $(\mathrm{Zn}(1))$ are slightly distorted. As shown in figure $2 \mathrm{c}$, the orientation of $\mathrm{Zn}(2)$ octahedron is different from that of $\mathrm{Zn}(1)$. The $\mathrm{Zn}$ to $\mathrm{Zn}$ separation is $3.8101(8) \AA$, which is about $1.5 \AA$ shorter than the typical Zinc-Zinc bond distance found in dizincocenes $\mathrm{R}-\mathrm{Zn}-\mathrm{Zn}-\mathrm{R} .{ }^{14}$ The $\mathrm{Zn}-\mathrm{N}$ distances fall in the range from 2.189(3) $\AA$ (N(3)-Zn(2)) to 2.118(3) $\AA$ (N(8)-Zn(1)) and the average $\mathrm{Zn}-\mathrm{N}$ distance is $2.151 \AA$. The $\mathrm{Zn}-\mathrm{O}$ distances are in the range from 2.071(3) to 2.123(3) $\AA$. The $\mathrm{N}-\mathrm{Zn}(2)-\mathrm{N}$ bond angles around $\mathrm{Zn}(2)$ varies from $89.43(11)^{\circ}$ to $91.25(11)^{\circ}$. The $\mathrm{O}-\mathrm{Zn}(1)-\mathrm{O}$ bond angles around $\mathrm{Zn}(1)$ falls from $87.22(14)^{\circ}$ to $90.93(15)^{\circ}$. The $\mathrm{O}-\mathrm{Zn}(1)-\mathrm{N}$ bond angle around $\mathrm{Zn}(1)$ shows a wide range from $86.40(13)^{\circ}$ to $91.16(13)^{\circ}$. The $\mathrm{N}-\mathrm{Zn}(1)-\mathrm{N}$ bond angle around $\mathrm{Zn}(1)$ also exhibits a wide range from $89.32(12)^{\circ}$ to $94.20(11)^{\circ}$.

\subsection{Structural comparisons}

The molecular structure of $\mathbf{Z n T}$ is comparable with the counter ion of the recently reported decavanadate complex,
Table 3. Comparison of important bond lengths and angles of $\mathbf{Z n T}, \mathbf{Z n} \mathbf{T}^{\mathbf{E}}$ and $\mathbf{Z n} \mathbf{T}^{\mathbf{V}}$.

\begin{tabular}{|c|c|c|c|}
\hline & $\mathrm{ZnT}$ & $\mathbf{Z n} \mathbf{T}^{\mathbf{E} 10}$ & $\mathbf{Z n T}^{\mathbf{V} 11}$ \\
\hline \multicolumn{4}{|l|}{ Bond lengths $(\AA)$} \\
\hline$d \mathrm{Zn}$ to $\mathrm{Zn}$ & 3.810 & 3.805 & 3.815 \\
\hline$a v . d \mathrm{Zn}-\mathrm{N}$ & 2.151 & 2.146 & 2.149 \\
\hline av. $d \mathrm{Zn}-\mathrm{OH}_{2}$ & 2.096 & 2.120 & 2.118 \\
\hline \multicolumn{4}{|l|}{ Bond angles (deg) } \\
\hline $\begin{array}{l}\angle \mathrm{N}-\mathrm{Zn}-\mathrm{N} \\
\text { range }\end{array}$ & $\begin{array}{l}89.32(12) \text { to } \\
94.20(11)\end{array}$ & $\begin{array}{c}89.3(1) \text { to } \\
92.0(1)\end{array}$ & $\begin{array}{l}87.1(2) \text { to } \\
95.92(19)\end{array}$ \\
\hline $\begin{array}{l}\angle \mathrm{H}_{2} \mathrm{O}-\mathrm{Zn}-\mathrm{OH}_{2} \\
\quad \text { range }\end{array}$ & $\begin{array}{l}87.22(14) \text { to } \\
90.93(15)\end{array}$ & $84.7(1)$ & $\begin{array}{c}82.20(19) \text { to } \\
93.01(17)\end{array}$ \\
\hline \multicolumn{4}{|c|}{ Torsion angles (deg) } \\
\hline $\mathrm{Zn}-\mathrm{N}-\mathrm{N}-\mathrm{Zn}$ & $\begin{array}{l}8.86,1.55 \\
2.50,-8.86 \\
-1.55,-2.50\end{array}$ & 7.4 & $\begin{array}{c}9.52,2.51 \\
3.19,-0.62 \\
-6.11,-5.99\end{array}$ \\
\hline
\end{tabular}

$\mathbf{Z n T}^{\mathbf{V}}$, where the $\left[\mathrm{Zn}_{3}(\mathrm{Htrz})_{6}\left(\mathrm{H}_{2} \mathrm{O}\right)_{6}\right]^{6+}$ was formed unexpectedly. ${ }^{11}$ The important structural matrices of $\mathbf{Z n T}, \mathbf{Z n} \mathbf{T}^{\mathbf{V}}$ and $\mathbf{Z n} \mathbf{T}^{\mathbf{E}}$ are listed in table 3. Although, in a way the zinc trimer core $\left[\mathrm{Zn}_{3}(\mathrm{Htrz})_{6}\left(\mathrm{H}_{2} \mathrm{O}\right)_{6}\right]^{6+}$ in $\mathbf{Z n T}$ looks similar to that of $\mathbf{Z n} \mathbf{T}^{\mathbf{V}}$, surprisingly, the structural metrics of $\mathbf{Z n T}$ is considerably different from $\mathbf{Z n} \mathbf{T}^{\mathbf{V}}$. For example, the $\mathrm{Zn}-\mathrm{N}$ bond distances in $\mathbf{Z n} \mathbf{T}^{\mathbf{V}}$ are not equal and twelve different bond distances were observed, while six different bond distances of $\mathrm{Zn}-\mathrm{N}$ are observed in ZnT. Unlike $\mathbf{Z n T}$, the six different $\mathbf{Z n}-\mathrm{OH}_{2}$ bond distances are noticed in $\mathbf{Z n} \mathbf{T}^{\mathbf{v}}$. However, the average zinc to zinc separation, $\mathrm{Zn}-\mathrm{N}$ and $\mathrm{Zn}-\mathrm{OH}_{2}$ bond distances of $\mathbf{Z n T}, \mathbf{Z n} \mathbf{T}^{\mathbf{V}}$ and $\mathbf{Z n} \mathbf{T}^{\mathbf{E}}$ are nearly comparable. Notably, considerable deviations in the $\mathrm{N}-\mathrm{Zn}-\mathrm{N}$ and $\mathrm{H}_{2} \mathrm{O}-\mathrm{Zn}-\mathrm{OH}_{2}$ bond angles are observed between $\mathbf{Z n T}$, $\mathbf{Z n} \mathbf{T}^{\mathbf{V}}$ and $\mathbf{Z n} \mathbf{T}^{\mathbf{E}}$. Similarly, the $\mathrm{Zn}-\mathrm{N}-\mathrm{N}-\mathrm{Zn}$ torsion angles of $\mathbf{Z n} \mathbf{T}, \mathbf{Z n} \mathbf{T}^{\mathbf{V}}$ and $\mathbf{Z n} \mathbf{T}^{\mathbf{E}}$ are not comparable.

\section{Conclusion}

In summary, the first rational synthesis of well defined hexanitrate salts of $\left[\mathrm{Zn}_{3}(\mathrm{Htrz})_{6}\left(\mathrm{H}_{2} \mathrm{O}\right)_{6}\right]^{6+}(\mathbf{Z n T})$ is reported. Solid state structure of $\mathbf{Z n T}$ revealed that the formation of a rare zinc trimer bridged by six 1,2,4triazole ligands, where the zinc atoms are on the same line. Furthermore, for the first time the spectral and thermal properties of $\mathbf{Z n T}$ are reported.

\section{Supporting Information}

FT-IR spectrum and CheckCIF report are available free of charge via the Internet at www.ias.ac.in/chemsci. CCDC 944805 contains the supplementary crystallographic data for this paper. This data can be obtained free 
of charge from the Cambridge Crystallographic Data Centre via www.ccdc.cam.ac.uk/data_request/cif or from the Cambridge Crystallographic Data Centre, 12 Union Road, Cambridge CB2 1EZ, UK; fax: +44 1223336 033; or e-mail: deposit@ccdc.cam.ac.uk.

\section{Acknowledgements}

We thank the DST, New Delhi (SR/FT/CS94/2010) and IIT Hyderabad for the financial support. NB thanks UGC for the fellowship.

\section{References}

1. (a) Steed J W and Atwood J L 2013 In Supramolecular Chemistry (New York: John Wiley); (b) Lehn J-M 1995 In Supramolecular Chemistry: Concepts and Perspectives (Weinheim: $\mathrm{VCH}$ )
2. Caulder D L and Raymond K N 1999 Acc. Chem. Res. 32975

3. Saalfrank R W and Demleitner B In Perspectives in Supramolecular Chemistry 1999 J P Sauvage (ed.) (Weinheim: Wiley-VCH) Vol. 5 pp. 1-51

4. Uller E, Demleitner B, Bernt I and Saalfrank R W 2000 In Structure and Bonding M Fujita (ed.) (Berlin: Springer) Vol. 96 p. 149

5. Moore D S and Robinson S D 1988 Adv. Inorg. Chem. 32171

6. Parkin G 2004 Chem. Rev. 104699

7. Liu K, Shi W and Cheng P 2011 Dalton Trans. 408475

8. Haasnoot J G 2000 Coord. Chem. Rev. 131 200-202

9. Reimann C W and Zocchi M 1971 Acta Crystallogr. Sect. B 27682

10. Spek A L and Vos G 1983 Acta Cryst. C39 990

11. Xu W, Jiang F, Zhou Y, Xiong K, Chen L, Yang M, Feng R and Hong M 2012 Dalton Trans. 417737

12. Sheldrick G M 1990 Acta Crystallogr. Sect A 46467

13. Sheldrick G M SHELXL-97, Program for Crystal Structure Refinement, 1997 (Göttingen: Universität Göttingen)

14. Grirrane A, Resa I, Rodríguez A and Carmona E 2008 Coord. Chem. Rev. 2521532 